will be found a unique record of the changes which have taken place in the character of the feeding stuffs and fertilizers which are used by the farmers of the country. His services towards the purification of such materials have been very great, and his investigations were of importance in leading to the passage of the Fertilisers and Feeding Stuffs Acts in later years.

Dr. Voelcker became director of the Woburn Experimental Station also in 1884 , and this remained one of the chief interests of his life from that time onward. The Woburn experiments owe almost everything to his zeal and energy, and rarely has there been much more than a month since he took over charge when he has not visited the experimental station. He only relinquished his position as honorary director in 1936, just after an account of fifty years' experiment there had been published by himself and Sir John Russell. It is a source of great satisfaction that he was able to co-operate in bringing out this monument of what he regarded as, to a large extent, his life-work.

Dr. Voelcker had a special bent for applying scientific results to actual problems, especially agricultural problems. He had, in fact, an almost uncanny knack of extracting, from comparatively simple experiments, conclusions which would stand the test of practice, and, hence, he was in great demand as an adviser in agricultural difficulties. His interest in agriculture was profound, and nothing pleased him more than to spend time on a farm or to associate with those who were responsible for managing agricultural land in any capacity.

On the chemical side, Dr. Voelcker was a prominent member of many of the professional and other societies. He was an early member of the Institute of Chemistry and for long a member of its council. He was also a past president of the Society of Public Analysts, and an old member of the council of the Chemical Society. Apart from his scientific activities, he was a man of very wide interests. An athlete in his youth, when he was a well-known cross-country runner, and a sportsman later in life, he never lost his zest for the one or the other, and he could often be found on a Saturday afternoon attending the events of the London Athletic Club (of which he was twice president).

\section{Mr. C. W. S. Crawley}

WE regret to record the death of Mr. Charles William Scott Crawley, which occurred on November 9 at the Corner House, Charlbury, Oxon. Mr. Crawley was seventy-nine years of age and was a partner in the business of the well-known electrical instrument makers-now Nalder Bros. and Thompson, Ltd. $\mathrm{He}$ went into partnership with the well-known electrical instrument manufacturers, the late Mr. Francis $\mathrm{H}$. Nalder and his brother, Mr. H. Nalder, two years after the business had started. Mr. Soames was also a partner, and the letters N.C.S. on ammeters and voltmeters are familiar to all electricians.

Mr. Crawley designed many instruments, and was an expert in their actual construction. After he retired from Nalder Bros., he became a consulting engineer and spent much of his time in the Board of Trade Electrical Standards Laboratory, voluntarily assisting Mr. Rennie. He worked chiefly in the resistance room making accurate comparisons of the standards, some of which had been made by Nalder Bros. in 1892 for the electrical standards committee of the British Association. The work was very difficult as it was known that some of the B.A. coils had changed owing to acidity in the paraffin wax used for insulation. Major Cardew and Mr. Rennie had used them for measuring resistances sent to them for calibration. Mr. Crawley recognized that the weak point in most measurements of resistance was the determination of temperature. At his suggestion, Dr. Guillaume was asked to procure a thermometer of the highest precision.

The provision of a scale of corrections to the thermometer for changes due to the barometric pressure showed Crawley's scrupulous care. He invented 'build-up' boxes for passing from $0 \mathrm{ohms}$ to $10 \mathrm{ohms}$ and so on to $10,000 \mathrm{ohms}$, using only two mercury cups at a time.

At the International Conference on Electrical Units and Standards in 1908 he was one of the secretaries, the others being W. Duddell, F. E. (now Sir Frank) Smith and M. J. Collins of the Board of Trade. Mr. Crawley, who could converse fluently in French and German, was of great help in explaining matters to the delegates and in showing them around the laboratory of the Board of Trade.

When he went to live at Charlbury, near Oxford, Mr. Crawley equipped a workshop laboratory. $\mathrm{He}$ made an instrument for tracing and recording variations of earth currents between buried earth plates. He designed and constructed several barographs for recording variations of atmospheric pressure on a scale twenty times as large as that of a mercury barometer. One of these was sent for comparison of observations to the neighbouring radio station at Leafield. For many years Mr. Crawley was a member of the Institution of Electrical Engineers and a fellow of the Physical Society. He often attended their meetings and took part in the discussions. He was the pioneer of many new methods of making highprecision measurements which have greatly helped physical and electrical research.

We regret to announce the following deaths :

Sir Charles Bright, an authority on submarine and general telegraphy, on November 20, aged seventythree years.

Mr. Henry Crowther, formerly curator of the Leeds Museum, on November 29, aged eighty-nine years.

Prof. A. Lodge, formerly professor of pure mathematics in the Royal Indian Engineering College, Coopers Hill, president of the Mathematical Associa. tion in 1897-98, aged eighty-three years.

Dr. D. S. Macnair, known for his work in analytical chemistry, an inspector in charge of the scientific and technical instruction under the former Science and Art Department, on November 27, aged seventysix years. 